\title{
Role of Human Resources Information System (Hris) in Accelerating Organizational Effectiveness - It Companies Perspective \\ M. Anupa
}

\begin{abstract}
In the contemporary situation of modernization and globalization, organizations intensely depend upon mechanical headway and advancement in the field of Information Technology. Progressions in its field have opened up more up-to-date roads for associations and gave an upper hand by utilizing creative and modified arrangements. It has become a fundamental piece of the authoritative working and all the offices rely upon coordinated frameworks for getting sorted out, putting away, recovering, and looking into information. Today Internet and mechanization have encouraged openness, dependability, and exactness of data; improved authoritative viability, and gave an initiative edge by applying innovation in different tasks. HRIS or Human Resource Information System is an altered programming arrangement intended for assisting associations with robotizing and deal with their $H R$, finance, the executives, and bookkeeping exercises. HRIS influences the presentation of individuals, cycles, and key hierarchical methodologies via mechanizing key $\mathrm{HR}$ measures like enrolment, preparing, labour arranging, execution evaluation, and occupation examination and plan. The examination on HRIS should be done to show how the precise course of action of HR rehearses causes associations to accomplish their objectives and adjusts itself to the business procedure that it seeks after. HRIS - its information, selection, helpfulness, and interaction should be passed on to individuals so they use the advantages of HRIS to the ideal level. The point of this investigation is the act of documenting and its refreshing in chosen programming organizations in India. Additionally, it will likewise recommend sorting out its acts of HR into sound and adjusted HRIS rehearses that will profit the association to lessen its desk work and the touchy issue - protection can be kept up to the office. Its openness can likewise be guaranteed with the assistance of the reception of such kind of framework. So essentially, such investigations are should have been done to advise the value regarding receiving innovation in the working environment and recommends how rapidly it very well may be embraced and changed to a standard method of practices.
\end{abstract}

Key Words: HRIS, Information Technology, Automation, Accessibility, Organizational Effectiveness

\section{INTRODUCTION}

$\mathrm{T}_{\mathrm{h}}$ The field of Human Resource Management has been constantly developing and the HR in the present situation is assuming an essential part than simply an emotionally supportive network. The human Resource work fundamentally manages the representatives, businesses, and all individuals who are identified with the association. It is intended to improve representative profitability, execution and adjust the labour force to the business.

Manuscript received on February 19, 2021.

Revised Manuscript received on February 23, 2021.

Manuscript published on February 28, 2021.

* Correspondence Authors

M. Anupa*, Research Scholar, Department of Business Management Studies, UCCBM, Osmania University, Hyderabad-500007 Email ID: anupa.yadav.aky@gmail.com

(c) The Authors. Published by Blue Eyes Intelligence Engineering and Sciences Publication (BEIESP). This is an open access article under the CC BY-NC-ND license (http://creativecommons.org/licenses/by-nc-nd/4.0/)
HR programming motorizes the everyday general and managerial capacities performed by the HR office, upgrades by and large worker efficiency and execution. HRM applications can be utilized for refreshing and recording representative data, its use can make the enlistment cycle stronger and more successful. HRMS encourages candidate following, meeting, and affirmation measure. Aside from this, the labour force organization systems can be smoothed out and it can produce different expense points of interest to the associations by smoothing out different practical activities. More or less, HRMS offers particular points of interest to the associations via robotizing different elements of HRM, in this way lessening the remaining task at hand of the HR office and expanding the proficiency of the office by normalizing key HR measures. Associations in the twentyfirst century are feeling the squeeze of decreasing the expense of tasks and the pressing factor of being receptive to the nearby clients' requests. It is more extreme for administration arranged associations, similar to; college, telecom, drug, inn, aircraft, bank, and so on the accomplishment of these associations for the most part relies upon the efficiency and conduct of their representatives. Besides, fulfilled workers are essential to building fulfilled clients. This is more unique in the financial business where workers connect with customers on an everyday schedule. In this way, to improve the productivity of bank workers, the human asset (HR) division needs to assemble a coordinated data innovation empowered human asset the executive's framework. Human Resource Information System (HRIS) is utilized to assemble and keep up the information that depicts HR, changing information into data and afterward announcing the data to clients. HRIS quickens the viable detailing and usage of HRM exercises. Thus, the regions that a coordinated HRIS cover HRIS is faculty organization, compensation organization, leave/nonattendance recording, expertise stock, clinical history, execution evaluation, preparing and improvement, HR arranging, enlistment, profession arranging, dealings, and so on Notwithstanding having a few advantages of HRIS-empowered organizations, they are neglected to appreciate its full advantages. A review led by the Institute of Management and Administration in the year 2002 demonstrated that the most concerning issues in overseeing HRIS include: the absence of staff, absence of spending plan, issues with time the executives, need to work with different divisions, and absence of data innovation uphold. Since these are fairly broad snags that can identify with any data framework, a rundown of more explicit obstructions while executing and overseeing HRIS, would include:

Published By:
Eyes Intelligence Engineering

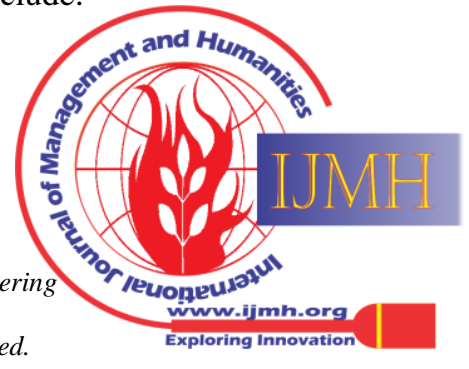


hazy about the key people answerable for essential HRIS plan, a few public laws and may make intricacy in detailing

HR arrangements, the danger of losing individual information that HRIS incorporates, and hard to gauge the profit from speculation (ROI) of HRIS because of its elusiveness of ROI of HRIS. In this research, an endeavour is made to investigate the areas of HRIS application in IT organizations and notice its advantages empowered HRM. Accentuation is likewise given on distinguishing the purposes behind being an inability to misuse the full advantages of HRIS.

\section{REVIEW OF LITERATURE}

Repel (2020): HRIS can fill in as an indispensable key device as it imparts pivotal information to the administration identified with enrolment and maintenance systems which can be lined up with the general corporate methodology for understanding the hierarchical goals of development. Furthermore, by utilizing HR applications, an organization can ascertain the general expenses brought about per worker and their consequences for the business all in all.

Hussain, Wallace, and Cornelius (2019): Over the most recent couple of a long time there has been an impressive development in the quantity of associations gathering, putting away, checking, and investigating data in regards to their human abilities with the utilization of Human Resource Information Systems (HRIS) programming or different kinds of programming which incorporate HRIS usefulness HRIS alludes to an orderly method for a social affair, putting away, keeping up, and recuperating information needed by an association about their HR, workforce exercises and hierarchical attributes.

Tyson, Shelbie, and Leighton (2018): A coordinated HRIS may have a wide scope of uses from basic bookkeeping pages to complex figuring's performed without any problem. The meaning of the execution of HRIS fluctuates among associations. Some utilize it to lessen costs, others to quicken better correspondence, and some utilize it to re-arrange HR exercises to build the office's essential commitment.
Ngai and Wat (2017): Found that the best advantages of the usage of HRIS were the fast reaction and admittance to data that it brought. Besides, the utilization of an HRIS would limit HR-related expenses via computerizing data and diminishing the quantity of HR representatives; by encouraging workers to screen and control their very own data; and by allowing administrators to get to significant data and information, conducts examinations, decide, and speak with others without speaking with an HR proficient with the undoubted advantages of HRIS, associations than any time before are more forceful to utilize HRIS. In any case, they are not in the situation to appreciate it because of certain hindrances. Krishnan and Singh (2016): investigated the issues and boundaries looked by nine Indian associations in actualizing and overseeing HRIS and the discoveries of the examination were the absence of information on the HR division about HRIS and absence of significance given to the HR office in these associations.

\section{OBJECTIVE OF THE STUDY}

The two main objectives of the study are to know the applicability/viability of HRIS in software companies and to study the perception of their employees towards the benefits of HRIS.

\section{RESULTS \& DISCUSSION}

Table -1: Data Validity Test

\begin{tabular}{|c|c|c|}
\hline P Val. & Std. Val. & Decision Criterion \\
\hline .932 & .70 & Accepted \\
\hline
\end{tabular}

Table -2: Knowledge of HR People about HRIS

\begin{tabular}{|l|l|l|}
\hline Particulars & $\begin{array}{l}\text { Number-HRIS } \\
\text { specialists }\end{array}$ & $\%$ \\
\hline Experts in HRIS & 40 & 80 \\
\hline Moderate in HRIS & 10 & 20 \\
\hline $\begin{array}{l}\text { Total Number of } \\
\text { Respondents }\end{array}$ & 50 & 100 \\
\hline
\end{tabular}

Table-3: The organizations which are adopted HRIS will offer more opportunities to its employees

\begin{tabular}{|c|c|c|c|c|c|c|}
\hline Particulars & HR Issues & Strongly Disagree & Disagree & No comment & Agree & Strongly Agree \\
\hline $\begin{array}{l}\text { Employees of an } \\
\text { Organization }\end{array}$ & $\begin{array}{l}\text { Good treatment } \\
\text { of management }\end{array}$ & 5 & 5 & 5 & 15 & 20 \\
\hline Employers/Owners & $\begin{array}{l}\text { Promising good } \\
\text { work culture }\end{array}$ & 1 & 4 & 10 & 30 & 5 \\
\hline Clients & $\begin{array}{l}\text { Improved choice } \\
\text { for selecting } \\
\text { good service } \\
\text { provider }\end{array}$ & 2 & 4 & 4 & 10 & 30 \\
\hline Sources of Recruitment & $\begin{array}{l}\text { Gap Fulfilment } \\
\text { between HR } \\
\text { demand and } \\
\text { Supply of } \\
\text { Candidates }\end{array}$ & 4 & 2 & 12 & 12 & 20 \\
\hline Government & $\begin{array}{l}\text { Ensuring fair HR } \\
\text { practices }\end{array}$ & 0 & 6 & 2 & 22 & 10 \\
\hline
\end{tabular}


To discover whether the respondents accept that HRIS empowered associations to offer greater freedom to be educated in regards to HR-related issues by guaranteeing open access for all the above inquiries has been posed. Out of 50 respondents, $30(60 \%)$ accept that the utilization of HRIS gives an extra advantage in reasonable treatment by the business while 10 respondents (20\%) think it has no compelling task to carry out in reasonable treatment. About $90 \%$ (45) of the respondents concurred that HRIS empowered associations to have focal points of choosing the correct contender for them over the customary associations.
The respondents' assessment on its pertinence for clients to choose the correct specialist co-op isn't extremely persuading as just 15 respondents trust it has application while 12 respondents have an assessment against it. 8 respondents offered no remark on it. Practically all the respondents have offered their input for its wide extension in enrolling offices to connect between the HR interest of various associations and the stock of right up-and-comers best fitted for every individual association. 25 respondents (50\%) feel that the public authority can guarantee the reasonable treatment of representatives by various associations through severe observing by utilizing the data gave through HRIS.

Table-4: Applications of HRIS in different process of an organization

\begin{tabular}{|l|l|l|l|l|l|}
\hline Areas & Not important at all & Not That Important & Neutral & Important & Very Important \\
\hline $\begin{array}{l}\text { Recruitment \& } \\
\text { Selection }\end{array}$ & 0 & 0 & & & \\
\hline $\begin{array}{l}\text { Training\& } \\
\text { Development }\end{array}$ & 0 & 0 & 12 & 15 & 23 \\
\hline $\begin{array}{l}\text { Payrolls } \\
\text { Management }\end{array}$ & 0 & 14 & 17 & 19 & 14 \\
\hline
\end{tabular}

Among various areas of uses of HRIS in HRM, measure respondents have given the most elevated significance on enlistment and determination measure as it is found from the investigation that about $94.28 \%$ (33 out of 35) trust it gives a larger number of advantages than customary frameworks. The second region of HRIS application that gives more advantage than the customary framework as depicted by them is finance with $82.86 \%$ respondents see while preparing and improvement are in the last position that infers advantage for the example associations among the previously mentioned three areas.

Table-5: Effectiveness of HRIS in HR functions

\begin{tabular}{|l|l|l|l|l|}
\hline Title & \multicolumn{3}{|l|}{ Frequency } & \multicolumn{2}{l|}{ Percentage } \\
\hline Process and methods of HR & 20 & 15 & 57.1 & 44.9 \\
\hline HR Planning & 23 & 12 & 65.71 & 34.29 \\
\hline Time saving in R\&S & 19 & 16 & 54.28 & 45.71 \\
\hline Time saving in Training & 15 & 15 & 50 & 50 \\
\hline Time saving in Record Keeping & 17 & 13 & 56.7 & 43.3 \\
\hline Data Sharing & 17 & 13 & 56.7 & 43.3 \\
\hline
\end{tabular}

The respondents have offered the input on the part of HRIS in the HR Process for saving time. The outcomes show a blended reaction about its part in saving time having a practically equivalent reaction for both yes and no. Still among the respondents, the most noteworthy $65.71 \%$ of the respondent think it saves time in HR arranging while $63.3 \%$ trust it has a job in saving time in Strategic HR. Then again, about half of the respondents think HRIS has no task to carry out in saving time in preparing.

Table-6: Cost Cutting \& HRIS

\begin{tabular}{|c|c|c|c|c|}
\hline \multirow[b]{2}{*}{ Particulars } & \multicolumn{2}{|c|}{ Frequency } & \multirow[b]{2}{*}{ Mean } & \multirow[b]{2}{*}{ Standard Deviation } \\
\hline & Yes & No & & \\
\hline Reduction of Cost in R \& S & 15 & 15 & 50.06 & 0.50855 \\
\hline Less Training Cost & 20 & 10 & 66.72 & 0.47646 \\
\hline Avoidance of Record Keeping Cost & 26 & 04 & 86.7 & 0.34475 \\
\hline Lesser Data Sharing Cost & 23 & 07 & 76.7 & 0.43018 \\
\hline No Cost of Documentation & 22 & 08 & 73.3 & 0.44978 \\
\hline
\end{tabular}

As appeared in the above table the discoveries of the review uncover that HRIS has a vital task to carry out in saving expense for record-keeping as about $86.7 \%$ of the respondents have their assessment for its part in saving time. Also, respondents accept that it assumes part in saving expenses for all the territories of preparing, data sharing, and documentation.

Blue Eyes Intelligence Engineerin

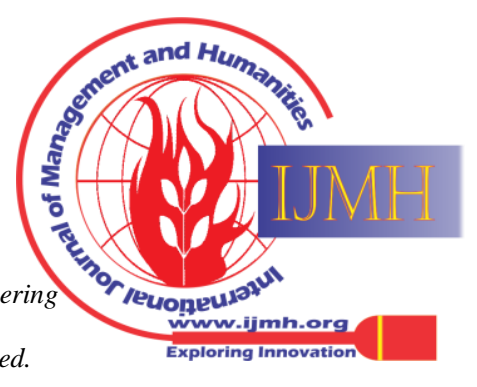




\section{CONCLUSION}

It is discovered that HRIS is being utilized in software companies in three unique zones of a) Recruitment and determination b) Training and Development c) Payroll. Among various regions of uses of HRIS in the HRM, measure respondents have given the most elevated significance on enrolment and choice which is $98.28 \%$ (48 out of 50), and the second region of HRIS which is profiting the firm is finance with $82.86 \%$. The aftereffect of the jobs of HRIS in saving time showed a blended reaction. The review uncovers that HRIS has a vital task to carry out in saving expense for record-keeping as about $86.7 \%$. the fundamental hindrances against the utilization of HRIS are the capacity of HRIS to check Nepotism, Threat of joblessness, and protection issue. This examination has given significant information and data to banking specialists about the significance of HRIS in saving time and cost in the HRM cycle like Recruitment and choice, preparation and improvement, finance handling, and so on It tends to be inferred that the banks which can introduce HRIS will diminish the expense and time in the HRM cycle by a considerable amount.

\section{REFERENCES}

1. SinEiE, D., Polo $\pi$ ki VokiE, N. (2007), "Integrating internal communications, human resource management and marketing concepts into the new internal marketing philosophy", Working paper series, Paper No. 07-12, Faculty of economics and business, Zagreb.

2. ArneriE, J., Garbin PraniEeviE, D., TadiE, I. (2007), "The Use of human resource information systems (HRIS) in Croatian hotels on the Adriatic coast: A survey", Global Business and Economics Antology, Vol. 1, pp. 110 - 121.

3. MarkiE, D., Horvat, J., Ore $\pi$ ki, D. (2011), "Human Resource Information Systems in Croatian Companies", Proceedings of ITI 2011, Zagreb: SveuEilizni raEunski centar, pp. 415-420.

4. Bambir, D., Hutinski, A., Drozdova, M. (2010), "A Review of Some Basic Prerequisites for Human Resource Management Information Systems Implementation at the Universities", Proceedings of the 21 st Central European Conference on Information and Intelligent Systems, Varaadin: Fakultet organizacijei informatike, pp. 297-303.

5. Ngai, E., Law, C., Chan, S., Wat, F. (2008), "Importance of the Internet to human resource functions in Hong Kong", Personnel Review, Vol 37, No. 1, pp. 66-84.

6. Singh, H. P., Jindal, S., Samim, S. A. (2011), "Role of Human Resource Information Systems in Banking Industry of Developing Countrie"s, The First International Conference on Interdisciplinary Research and Development, 31 May - 1 June 2011, Thailand

7. Beckers, A. M. and Bsat, M. Z. (2002), "A DSS classification model for research in human resource information systems", Information Systems Management, Vol. 19 No. 3, pp. 41-50.

8. Panayotopoulou, L., Vakola, M., Galanaki, E. (2007), "E-HR adoption and the role of HRM: evidence from Greece", Personnel Review, Vol. 36 No. 2, pp. 277-294.

9. Ngai, E., Wat F. (2006), "Human Resource Information Systems: a review and empirical analysis", Personnel Review, Vol 35, No. 3, pp. 297-314.

10. Perry. E. (2010), "The benefits of using technology in human resource management", IGI global. Cranfield School of Management.

11. Ngai, E.W. and Wat, F.K. (2006). "Human resource information systems: a review and empirical analysis". Human Resource Information Systems, 35, 298-314.

12. Krishnan, S., \& Singh, M. (2006). "Issues and concerns in the implementation and maintenance of HRIS". Issues and concerns in the implementation and. Indian institute of management ahmedabad380015. Research and Publication Department in its series IIMA working papers with number WP2006-07-01.

13. Barron, M., Chhabra, D., Hanscome, R. \& Henson, R. (2004). "Exclusive Panel Discussion: Tips and Trends in HRIS", HR Focus, 81, 6-7.

14. Hussain, Z., Wallace, J. \& Cornelius, N. E. (2007). "The Use and Impact of Human Resource Information System on Human Resource Management Professionals", Information and Management, 44(1), 74-89.

Published By:

Blue Eyes Intelligence Engineerin

15. Awazu, Y. \& Desouza, K. C. (2003). "Knowledge Management", HR Magazine, 48(11), 107.

16. Kovach, K.A., Hughes, A.A., Fagan, P., \& Maggitti, P.G. (2002). "Administrative and strategic advantages of HRIS", Employment Relations Today, 29, 43-8.

\section{AUTHOR PROFILE}

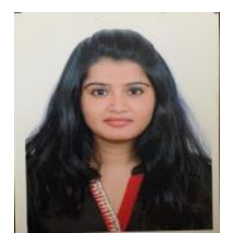

M. Anupa, Research Scholar, Department of Business Management Studies, University College of Commerce and Business Management (UCCBM), Osmania University, Hyderabad-500007 Email ID: anupa.yadav.aky@gmail.com 